\title{
Aplikasi Computer Assisted Instruction (CAI) Crafting Interior Rumah bagi Anak Usia Dini
}

\author{
Indah Jong ${ }^{\# 1}$, Narti Prihartini ${ }^{\# 2}$, Tursina ${ }^{\# 3}$ \\ \#Program Studi Informatika Fakultas Teknik Universitas Tanjungpura \\ Jl. Prof. Dr. H. Hadari Nawawi, Kota Pontianak, 78115 \\ indah.jong94@gmail. com \\ 2narti.prihartini@gmail.com \\ 3 tursina15@yahoo. com
}

\begin{abstract}
Abstrak - Computer Assisted Instruction (CAI) adalah media bantu pembelajaran yang menempatkan komputer sebagai piranti sistem pembelajaran individual, di mana siswa dapat berinteraksi langsung dengan sistem komputer yang sengaja dirancang atau dimanfaatkan oleh guru. Pada taman kanakkanak di masa modern ini sebagian besar pembelajaran dan pelatihan bahasa Inggris dimulai dengan memperkenalkan lingkungan sekitar termasuk benda-benda di dalam rumah. Menyikapi perkembangan pembelajaran anak usia dini, perlu adanya suatu aplikasi pendidikan yang didesain untuk guru sesuai dengan tingkat perkembangan anak usia 5 sampai dengan 6 tahun untuk menunjang pembelajaran bertemakan rumah. Tujuan dari penelitian ini adalah untuk menghasilkan aplikasi komputer yang memanfaatkan konsep CAI dengan model tutorial dan instructional games untuk mengenalkan nama benda-benda pada interior rumah dengan dua bahasa yaitu bahasa Inggris dan bahasa Indonesia. Metodologi penelitian yang dipakai mengacu pada pendekatan model ADDIE. Pengujian aplikasi menggunakan uji validasi yaitu ahli akademisi (PAUD), ahli CAI dan ahli multimedia. Hasil yang didapat dari validasi aplikasi menggunakan skala pengukuran Guttman ini mendapatkan nilai $95 \%$ untuk sisi akademisi PAUD, nilai 91,665\% untuk sisi CAI, dan nilai $75 \%$ untuk sisi multimedia, rata-rata nilai persentase akhir dari aplikasi ini adalah $87,223 \%$, sehingga aplikasi CAI crafting interior rumah bagi anak usia dini dirasa telah layak dalam memenuhi target pembelajaran.
\end{abstract}

Kata kunci-Computer Assisted Instruction (CAI), Tutorial, Instructional Games, PAUD, Rumah

\section{PENDAHULUAN}

Computer Assisted Instruction (CAI) adalah suatu bentuk pembelajaran yang menempatkan komputer sebagai piranti sistem pembelajaran individual, di mana siswa dapat berinteraksi langsung dengan sistem komputer yang sengaja dirancang atau dimanfaatkan oleh guru. Proses pembelajaran berupa sofware komputer yang meliputi: judul, tujuan, materi pembelajaran dan evaluasi pembelajaran. Model CAI yang dikembangkan yaitu drill and practice, tutorial, simulasi dan instructional games harus berorientasi pada tujuan pembelajaran bagi kepada standar kompetensi, kompetensi dasar dan indikator yang dicapai pada setiap kegiatan pembelajaran [1].

Sesuai dengan pandangan Departemen Pendidikan dan Kebudayaan (1994) sendiri telah menetapkan berbagai tema yang untuk membantu para guru TK dalam melaksanakan program kegiatan bagi anak TK dan tidak tertutup kemungkinan bagi guru untuk mengembangkan tema sendiri. Salah satu diantaranya adalah tema rumah yang meliputi: guna rumah, macam rumah, jenis rumah, bagian-bagian rumah, alat dan perkakas rumah, lingkungan rumah [2]. Menyikapi perkembangan pembelajaran anak usia dini, perlu adanya suatu aplikasi pendidikan yang didesain untuk guru dengan tingkat perkembangan anak.

Media pembelajaran kepada anak usia dini terutama komputer sudah banyak digunakan pada sekolah Taman Kanak-Kanak. Bermain sambil belajar dan belajar seraya bermain menjadi tujuan utama dalam kegiatan pembelajaran tersebut. Konsep Computer Assisted Instruction (CAI) diterapkan ke teknologi berbantuan komputer untuk dapat mempelajari crafting interior rumah. Tentu saja materi pembelajaran itu perlu dikemas sedemikian rupa sehingga anak tertarik untuk mempelajarinya. Tanpa disadarinya ketika anak tersebut bermain, masuk ke dalam proses pembelajar melalui permainan.

Berdasarkan masalah tersebut, diperlukan pemanfaatan teknologi komputer yang dapat membantu guru TK dalam mengajar tema rumah dengan menggunakan sarana visual yaitu aplikasi Computer Assisted Instruction (CAI) crafting interior rumah bagi anak usia dini. Model yang digunakan dalam aplikasi ini yaitu tutorial dan instructional games berisi penjelasan materi untuk guru dan anak-anak tersebut bisa langsung mencoba permainan (drag and drop). 


\section{URAIAN PENELITIAN}

\section{A. Computer Assisted Instrution (CAI)}

CAI merupakan suatu bentuk pembelajaran yang menempatkan komputer sebagai piranti sistem pembelajaran individual, di mana siswa dapat berinteraksi langsung dengan sistem komputer yang sengaja di rancang atau dimanfaatkan oleh guru. Ada beberapa model yang diterapkan dalam CAI [3].

1. Model Tutorial

Tutorial dalam program pembelajaran berbasis komputer ditujukan sebagai pengganti sumber belajar yang proses pembelajarannya diberikan lewat grafik, animasi, audio yang tampak pada monitor yang menyediakan pengorganisasian materi, soal-soal latihan dan pemecahan masalah. Jika respon siswa benar, komputer akan terus bergerak pada pembelajaran berikutnya, namun sebaliknya jika respon siswa salah komputer akan mengulangi pembelajaran sebelumnya atau bergerak pada salah satu bagian tertentu tergantung kesalahan yang dibuat.

\section{Model Instructional Games}

Tujuan instructional games adalah untuk menyediakan pengalaman belajar yang memberikan fasilitas belajar untuk menambah kemampuan siswa melalui bentuk permainan yang mendidik.

\section{Simulasi}

Model simulasi pada dassarnya merupakan salah satu strategi pembelajaran yang bertujuan untuk pengalaman belajaryang lebih konkret melalui ciptaan tiruan-tiruan untuk pengalaman yang mendekati suasana sebenarnya dan berlangsung tanpa resiko.

\section{Drills and Practice}

Model drills and practice adalah suatu model dalam pembelajaran dengan jelas melatih siswa terhadap bahan pelajaran yang sudah diberikan. Melalui model drills akan ditanamkan kebiasaan tertentu dalam bentuk latihan. Dengan latihan yg terus menerus maka akan tertanam dan kemudian akan menjadi kebiasaan.

\section{B. Pendidikan Anak Usia Dini (PAUD)}

Pendidikan anak usia dini (PAUD) adalah suatu proses pembinaan tumbuh kembang anak sejak lahir hingga umur enam tahun secara menyeluruh, yang mencakup aspek fisik dan nonfisik dengan memberikan rangsangan bagi perkembangan jasmani, rohani (moral dan spiritual), motorik, akal pikir, emosional, dan sosial yang tepat dan benar agar anak dapat tumbuh dan berkembang secara optimal [4].

\section{Pengenalan Benda-Benda dalam Rumah}

Sesuai dengan pandangan Departemen Pendidikan dan Kebudayaan (1994) sendiri telah menetapkan berbagai tema yang utnuk membantu para guru TK dalam melaksanakan program kegiatan bagi anak TK dan tidak tertutup kemungkinan bagi guru untuk mengembangkan tema sendiri. Salah satu diantaranya adalah tema rumah yang meliputi: guna rumah, macam rumah, jenis rumah, bagian-bagian rumah, alat dan perkakas rumah, lingkungan rumah.

\section{Skala Pengukuran dan Validasi Aplikasi}

Skala pengukuran merupakan kesepakatan yang digunakan sebagai acuan untuk menentukan panjang pendeknya interval yang ada dalam alat ukur, sehingga alat ukur tersebut bila digunakan dalam pengukuran akan menghasilkan data kuantitatif. Pada skala pengukuran Guttman akan didapat jawaban yang tegas, yaitu "ya-tidak"; "benar-salah"; "pernahtidak pernah"; "positif-negatif' dan Iain-lain. Data yang diperoleh dapat berupa data interval atau rasio dikhotomi (dua alternatif).

Skala Guttman selain dapat dibuat dalam bentuk pilihan ganda, juga dapat dibuat dalam bentuk checklist. Jawaban dapat dibuat skor tertinggi satu dan terendah nol. Misalnya untuk jawaban setuju diberi skor 1 dan tidak setuju diberi skor 0. Analisa dilakukan seperti pada skala Likert, yaitu dengan menggunakan rumus sebagai berikut:

$\mathrm{p}=(\mathrm{f} / \mathrm{n}) * 100 \%$

Keterangan:

$\mathrm{p}=$ Nilai persentase yang dicari

$\mathrm{f}=$ Jumlah frekuensi dikalikan dengan skor yang ditetapkan tiap jawaban

$\mathrm{n}=$ Skor ideal (skor tertinggi dikalikan dengan jumlah sampel)

Jika nilai persentase yang dicari mendekati $100 \%$, maka sistem/instrumen/aplikasi yang sedang diujikan terbukti dapat berjalan dengan baik dan sesuai dengan aspek yang diperlukan [5].

\section{E. Model ADDIE}

Model pengembangan dalam penelitian ini menggunakan model Analysis-Design-Development-ImplementationEvaluation (ADDIE) karena proses ini dianggap berurutan tetapi juga interaktif, di mana hasil evaluasi setiap tahap dapat membawa pengembangan pembelajaran ke tahap sebelumnya sehingga model ini memberikana kesempatan kepada pengembang desain pembelajaran untuk bekerja sama dengan para ahli isi, media dan desain pembelajaran dan menghasilkan produk berkualitas baik. [6].

\section{PERANCANGAN SISTEM}

\section{A. Perancangan Lingkungan Sistem}

Desain perancangan lingkungan sistem akan ditunjukan pada Gambar 1, 


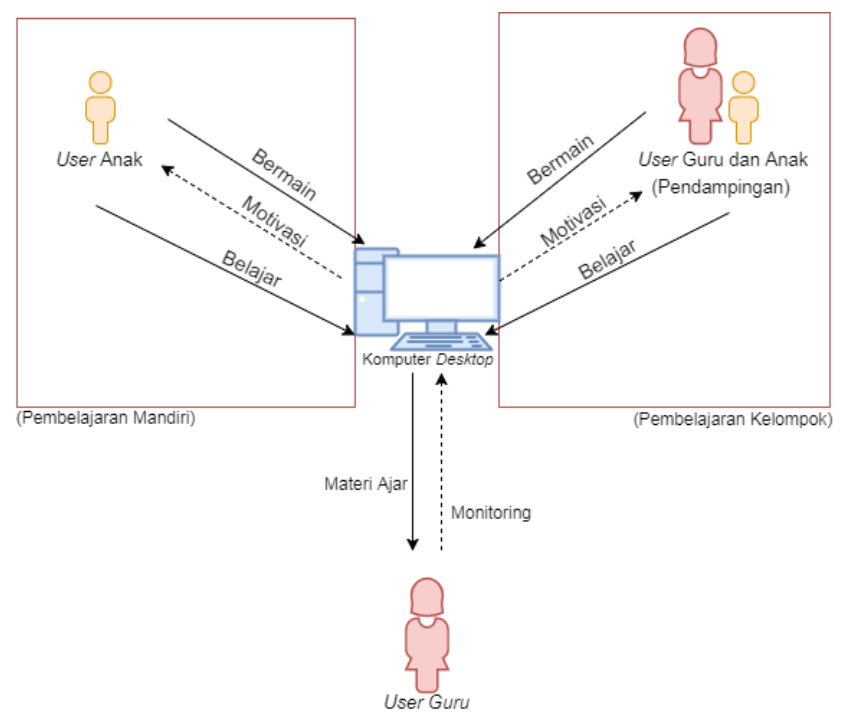

Gambar 1. Perancangan Lingkungan Sistem

Aplikasi tersebut tidak perlu koneksi pada internet sehingga anak-anak usia 5-6 tahun bisa langsung memainkan aplikasi pada komputer, tanpa harus instal aplikasi. Pembelajaran dengan bantuan komputer (CAI) dapat dilakukan oleh user anak secara mandiri. Jika user anak yang akan menggunakan aplikasi sudah menguasai pemakaian komputer, maka user anak tersebut dapat langsung memainkan aplikasi secara mandiri (individual learning). Namun, sebaiknya didampingi oleh guru atau orang dewasa yang mengerti menggunakan komputer, karena sasaran pengguna aplikasi ini adalah anak-anak TK yang masih berumur 5 sampai dengan 6 tahun. User guru dapat memperoleh materi ajar untuk mengenalkan benda-benda di rumah dengan berbahasa Indonesia dan bahasa Inggris serta memonitoring dari pembelajaran mandiri (individual learning) maupun pembelajaran kelompok (group learning).

\section{B. Langkah Penelitian}

Langkah-langkah penelitian diperlihatkan pada Gambar 2.

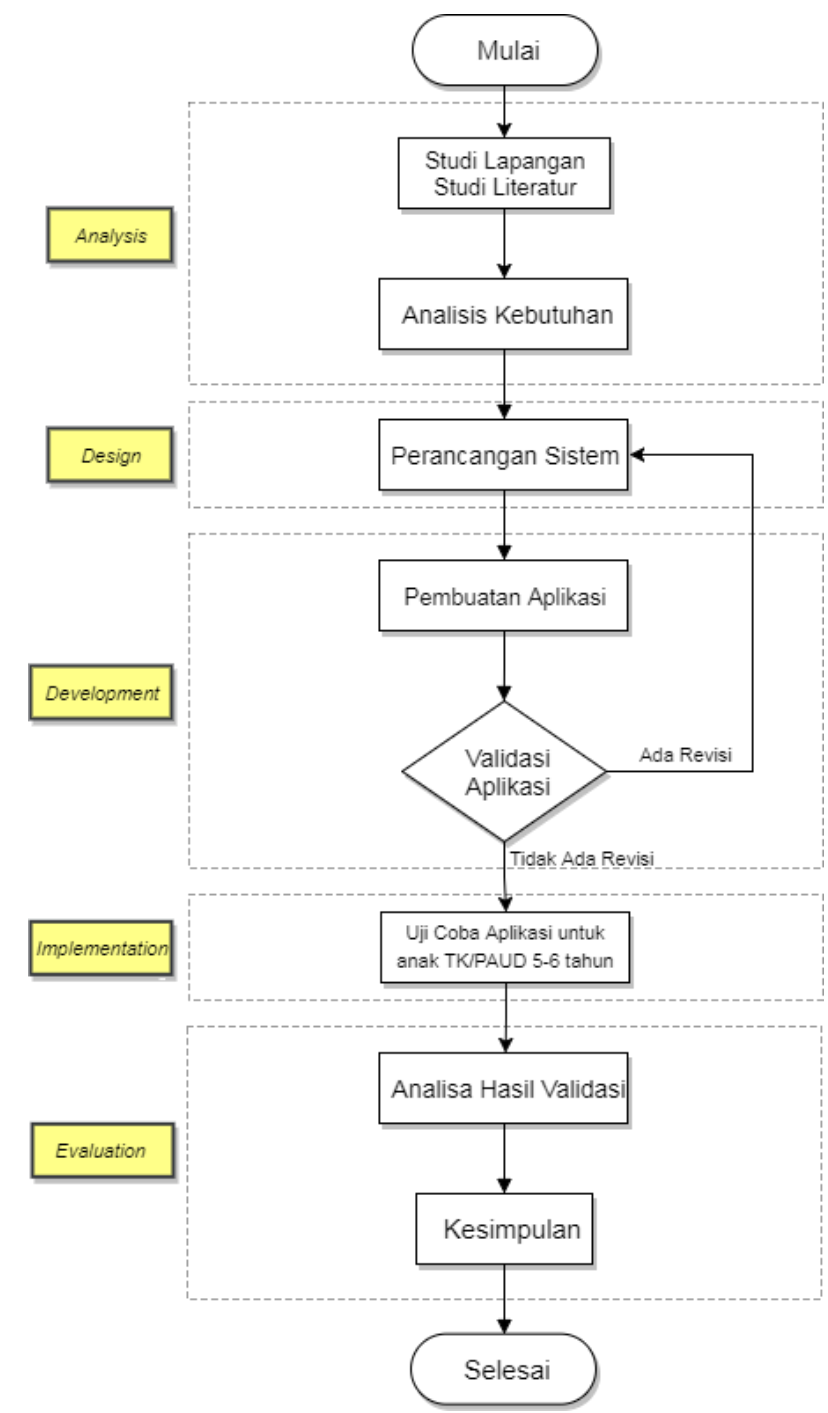

Gambar 2. Diagram Alir Penelitian

\section{ERD (Entity Relationship Diagram)}

Pernancangan Entity Relationship Diagram dapat dilihat pada Gambar 3.

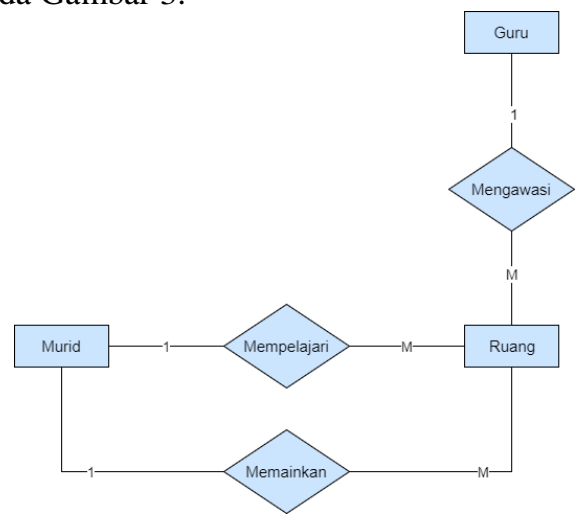

Gambar 3. Perancangan Entity Relationship Diagram 


\section{Hirarki Antarmuka Aplikasi}

Hirarki antarmuka pada aplikasi dapat diperlihatkan pada Gambar 4.

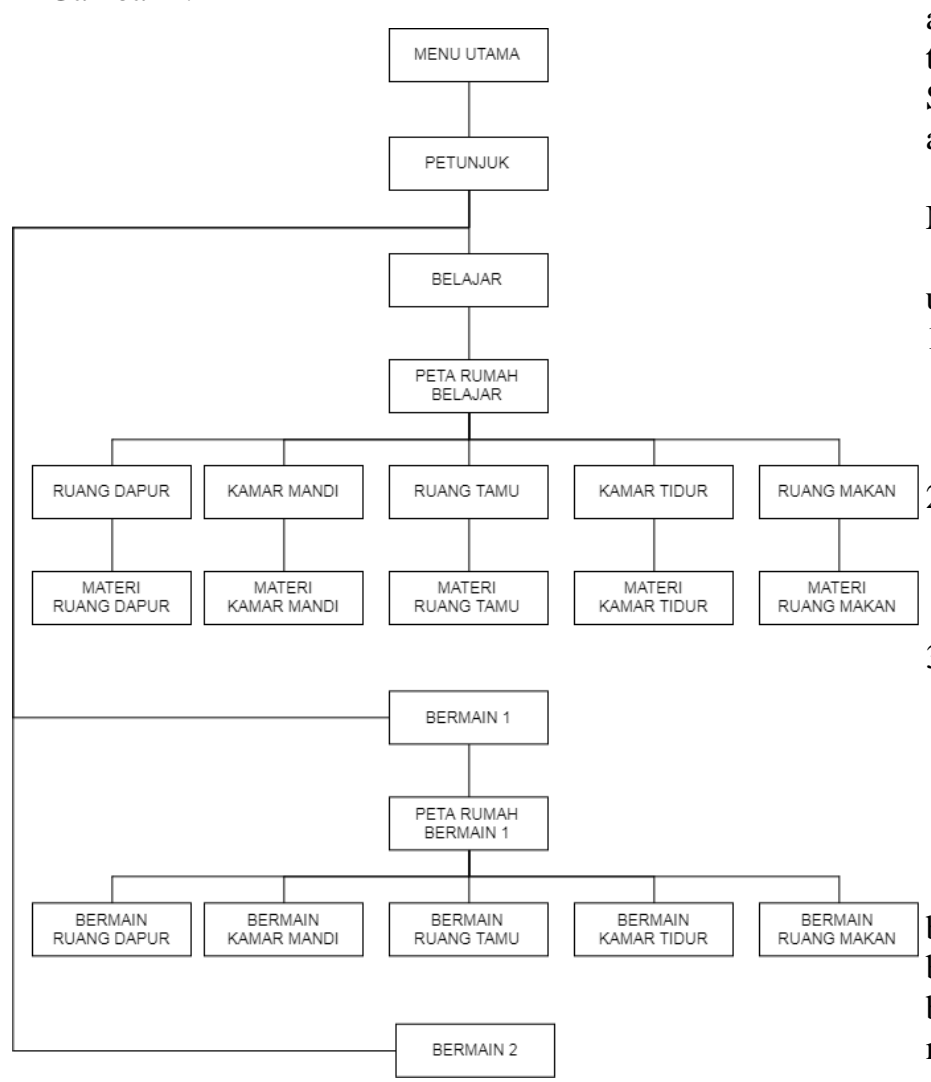

Gambar 4. Hirarki Antarmuka Aplikasi

\section{E. Storyboard dan Implementasi Aplikasi}

Storyboard dan implementasi aplikasi dapat dilihat pada Tabel 1 berikut ini.

Tabel 1. Storyboard dan Implementasi Aplikasi

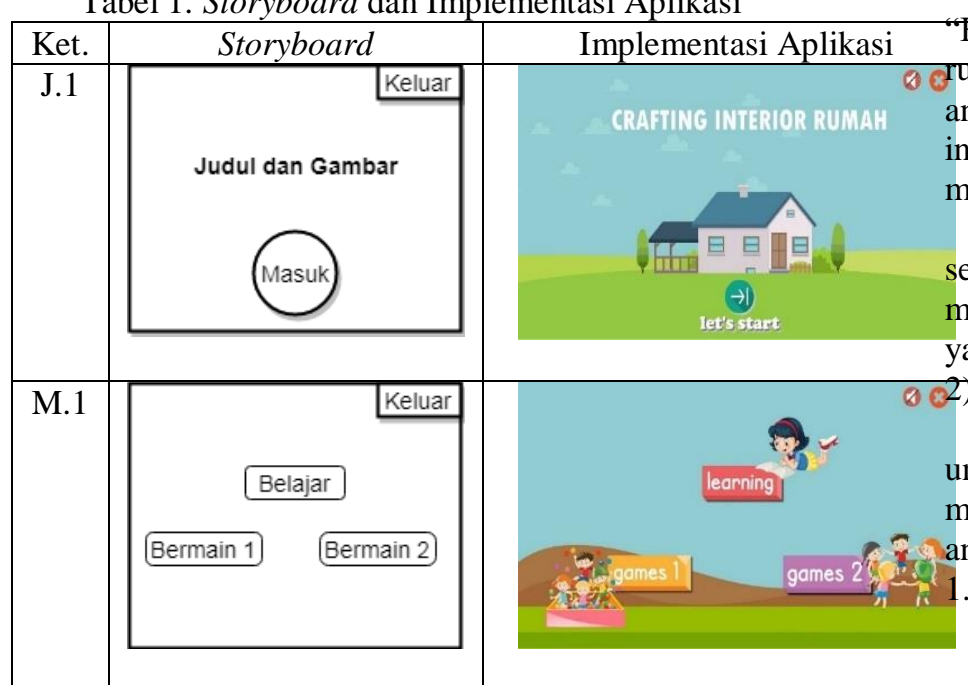

Keterangan:

\section{J.1 Antar Muka Scene Judul}

Scene pertama saat aplikasi dimainkan yaitu judul dari aplikasi adalah "CRAFTING INTERIOR RUMAH" berupa animasi bergerak dari atas ke bawah dan setelah itu terdapat tombol "Let's Start" untuk menuju ke scene menu utama. Suara instrumen otomatis di jalankan selama aplikasi dari awal dimainkan.

\section{M.1 Antar Muka Scene Menu Utama}

Ada tiga tombol pilihan menu yang ada pada scene menu utama, yaitu:

1. Tombol "learning", jika tombol menu ini ditekan maka user akan masuk ke menu interior rumah yang berisi pengenalan nama-nama benda di dalam rumah sesuai dengan ruangan.

2. Tombol "games 1", jika tombol menu ini ditekan maka user akan masuk ke menu bermain yang berisi permainan drag and drop gambar benda-benda ke bayangan yang tepat.

3. Tombol "games 2", jika tombol menu ini ditekan maka user akan masuk ke menu bermain yang berisi permainan drag and drop berupa gambar aktivitas ke ruangan yang tepat.

\section{F. Analisis Hasil Uji Coba dan Validasi Aplikasi}

Awalnya uji coba aplikasi dilakukan oleh peneliti sendiri berdasarkan hasil uji coba mandiri bahwa aplikasi CAI yang berjudul "Crafting Interior Home" sudah berfungsi dengan baik. Semua tombol aplikasi yang dibuat dapat diklik dan menuju scene yang dimaksud.

Aplikasi format ekstensi .swf dapat dioperasikan di semua jenis laptop atau komputer. Uji coba aplikasi ini dilakukan oleh guru dan anak-anak TK Global Maju Khatulistiwa kelas B berumur 5-6 tahun pada 6 laptop sekolah yang ada pada ruang kelas komputer sekolah tersebut. Jumlah siswa dalam ruangan kelas tersebut sebanyak 30 orang. Pada hari itu mereka belajar tentang pelajaran yang bertemakan "Kebutuhanku" dan di dalamnya termasuk pelajaran tentang runhah dan bagian-bagian yaitu interior rumah. Kemudian anak-anak tersebut diajarkan menyebutkan nama benda-benda interior rumah dalam bahasa Inggris dan bahasa Indonesia mehggunakan aplikasi ini.

Uji coba aplikasi selanjutnya dilakukan oleh 6 orang ahli, sekaligus untuk memvalidasi aplikasi yang bertujuan untuk mehgecek kelayakan aplikasi sebagai media pembelajaran yang ditinjau dari 3 sisi, yaitu 1) sisi akademisi (PAUD), 2) sisi CAI, 3) sisi multimedia.

Pada penelitian ini, skala pengukuran Guttman digunakan untuk validasi produk oleh pakar atau tenaga ahli yang akan menguji coba aplikasi yang telah dibuat [7]. Berikut ini adalah analisis terhadap setiap hasil validasi:

Analisis Hasil Uji Validasi Media Pembelajaran sisi Akademisi (PAUD)

Hasil validasi tersebut yaitu validator pertama adalah guru TK Global Maju Khatulistiwa dan validator kedua adalah 
dosen FKIP PG-PAUD UNTAN. Penilaian terhadap sisi akademisi (PAUD) aplikasi ini dirata-ratakan adalah sebesar $95 \%$ yang bisa dikategorikan mendekati nilai $100 \%$. Aplikasi ini terbukti layak dan telah memenuhi sebagian besar kriteria aplikasi pembelajaran yang sesuai dengan anak 5-6 tahun. Berikut ini adalah nilai persentase dari hasil uji kevalidan dari ahli akademisi (PAUD), yaitu:

a. Dosen FKIP PG PAUD

$$
\begin{aligned}
P & =\frac{f}{n} \times 100 \% \\
& =\frac{(1 \times 9)}{10} \times 100 \% \\
& =90 \%
\end{aligned}
$$

. Guru TK Global Maju Khatulistiwa

$$
\begin{aligned}
P & =\frac{f}{n} \times 100 \% \\
& =\frac{(1 \times 10)}{10} \times 100 \% \\
& =100 \%
\end{aligned}
$$

[1] Rusman. 2015. Model-Model Pembelajaran. Jakarta: PT

2. Analisis Hasil Uji Validasi Media Pembelajaran sisi CAI Kedua validator ahli CAI pada penelitian ini adalah dosen Teknik Informatika. Penilaian terhadap sisi CAI aplikasi ini dirata-ratakan adalah sebesar 91,665\% dan berikut ini adalah nilai persentase dari hasil uji kevalidan dari ahli CAI, yaitu 1) validator pertama $83,333 \%$ dan 2) validator kedua $100 \%$.

3. Analisis Hasil Uji Kevalidan Media Pembelajaran dari Sisi Multimedia

Validator pada validasi sisi ini adalah dua orang dosen Teknik Informatika UNTAN ahli multimedia yang mengajar mata kuliah yang berkaitan dengan materi pembelajaran berbasis multimedia. Hasil rata-rata penilaian tersebut didapatkan $75 \%$ dan aplikasi ini dikategorikan layak karena mendekati $100 \%$. Berikut ini adalah nilai persentase dari hasil uji kevalidan media pembelajaran dari sisi multimedia, yaitu 1) validator pertama $70 \%$ dan 2) validator kedua $80 \%$.

Secara keseluruhan nilai persentasi akhir dari aplikasi ini, yaitu:

$P=\frac{(9096+10096)+(83,33396+10096)+(7096+8096)}{3}=87,223 \%$ (4)

Nilai persentase akhir aplikasi didapat dari penjumlahan nilai persentase uji validasi dari sisi akademisi (PAUD), sisi CAI dan sisi multimedia kemudian dibagi 3, sehingga didapatkan nilai $87,223 \%$ yang artinya aplikasi ini secara keselurahan terbukti layak menjadi media pembelajaran crafting interior rumah dengan konsep CAI yang ditujukan untuk anak-anak usia 5 sampai dengan 6 tahun.

\section{KESIMPULAN/RINGKASAN}

Berdasarkan hasil analisis uji coba dan validasi terhadap aplikasi CAI crafting interior rumah bagi anak usia dini, dapat disimpulkan bahwa:

1. Penelitian berhasil membuat suatu aplikasi CAI tentang crafting interior rumah karena berdasarkan hasil validasi, aplikasi ini mendapatkan nilai 95\% untuk sisi akademisi PAUD, nilai 91,665\% untuk sisi CAI, dan nilai $75 \%$ untuk Raja Grafindo Persada.

[2] Depdikbud. 1994. Kurikulum Taman Kanak-Kanak. Jakarta.

[3] Rusman. 2013. Belajar dan Pembelajaran Berbasis Komputer. Mengembangkan Profesionalisme Abad 21. Bandung: Alfabeta.

[4] Firdania, Milda Surgani. 2016. Aplikasi CAI Berbasis Multimedia untuk Pengenalan Bagian Tubuh Manusia pada Anak Usia Dini. Pontianak, Indonesia: Jurnal Sistem dan Teknologi Informasi (JUSTIN) Vol.4, No. 1, 2016.

sisi multimedia serta aplikasi ini sudah diterapkan dalam pembelajaran TK Global Maju Khatulistiwa.

akhir keseluruhan dari aplikasi ini adalah 87, 223\% yang diasumsikan sebagai tingkat validitas yang tinggi.

[5] Sugiyono. 2012. Metode Penelitian Pendidikan. Bandung: Alfabeta.

[6] Mulyatiningsih, Endang. 2013. Pengembangan Model Pembelajaran. Yogyakarta: Universitas Negeri Yogyakarta.

[7] Eko, Ahmad, Tria Kusmanto. 2016. Pengelompokkan Kelas Menggunakan Self Organizing Map Neural Network pada SMKN 1 Depok. Jurnal Edukasi dan Penelitian Informatika (JEPIN) Vol. 2, No. 2, ISSN 24607041,2016. 